\title{
Indirect somatic embryogenesis of Piper hispidinervum L. and evaluation of the regenerated plants by flow cytometry
}

\author{
Paulo Cesar Alves de Sousa', Stênio Steferson Silva e Souza', Gabriela Ferreira Nogueira², \\ Inaê Mariê de Araújo Silva-Cardoso ${ }^{2}$ and Jonny Everson Scherwinski-Pereira ${ }^{3^{*}}$ (1)
}

\begin{abstract}
Background: Piper hispidinervum is a species native from the Amazon region with great economic potential, given its scientifically proven insecticidal properties. In this study, an efficient protocol of plant regeneration via indirect somatic embryogenesis has been established for the first time. In a first experiment, for the induction of calluses, foliar explants of non-discriminated accesses of P. hispidinervum were inoculated in MS medium supplemented with a-naphtalenacetic acid (NAA) and 6-benzylaminopurine (BAP), in different combinations. For a second experiment, foliar explants from five different accesses of P. hispidinervum ( $\mathrm{PH} 17, \mathrm{PH} 21, \mathrm{PH} 28, \mathrm{PH} 37$, and $\mathrm{PH} 39)$ were analyzed regarding the formation of calluses when cultivated in MS medium with $5 \mathrm{mg} \mathrm{L}^{-1} \mathrm{NAA}+2.5 \mathrm{mg} \mathrm{L}^{-1}$ BAP. To obtain somatic embryos-like structures, calluses were cultivated in MS medium with $10 \mathrm{mg} \mathrm{L}^{-1} \mathrm{NAA}+2.5 \mathrm{mg} \mathrm{L}^{-1}$ of BAP. The somatic embryos-like structures obtained were inoculated in MS medium devoid of growth regulators and the plantlets were subjected to acclimatization. Calluses and somatic embryos-like structures were subjected to anatomical analysis and genetic stability of regenerated plants was analyzed by flow cytometry.

Results: The treatments $2.5 \mathrm{mg} \mathrm{L}^{-1}$ BAP and $5 \mathrm{mg} \mathrm{L}^{-1} \mathrm{NAA}+2.5 \mathrm{mg} \mathrm{L}^{-1}$ BAP, after 60 days of cultivation, provided each $32 \%$ of primary callus, not being verified the formation of calluses in medium devoid of BAP. It was found that accesses differed among them with respect to the formation of primary calluses, with emphasis on accesses $\mathrm{PH} 28$, $\mathrm{PH} 37$, and PH39, with mean percentage of 95.3\%. Regarding the percentage of embryogenic calluses and formation of somatic embryos-like structures, there were no statistical differences between accesses, with mean values of $90.6 \%$ and $77.3 \%$, respectively. The somatic embryos-like structures of $P$. hispidinervum have conspicuous morphoanatomical similarities with the zygotic embryo, and flow cytometry analysis showed no significant variation in nuclear DNA size among plants regenerated in vitro and plants coming from seed germination, which indicates ploidy level stability.

Conclusion: This protocol is the first cited in the literature that demonstrates an efficient micropropagation process by somatic embryogenesis of $P$. hispidinervum. It can be used either to enable large-scale vegetative production or to subsidize germplasm conservation or genetic engineering of $P$. hispidinervum.
\end{abstract}

Keywords: Piperaceae, Morphogenesis, Somatic embryos, Plant regeneration, Cellular DNA content

\footnotetext{
*Correspondence: jonny.pereira@embrapa.br

${ }^{3}$ Embrapa Recursos Genéticos e Biotecnologia, Av. W5 Norte (final),

Brasília, DF 70770-917, Brazil

Full list of author information is available at the end of the article
}

\section{Background}

The species of Piper are not only plants commonly used as seasonings in food, but are also producers of secondary metabolites with various biological effects on human health, as well as scientifically proven antibacterial, antifungal, and insecticidal properties [1]. 
Among these species, Piper hispidinervum C. DC., a species native to the Brazilian Amazon and popularly known as long pepper, has attracted the attention of the scientific community and producers due to its high safrole content [2], which can reach up to 97\% [3]. Safrole, initially exploited in Sassafras albidum plants, nowadays threatened with extinction, is considered one of the most used essential oils in the world [4] and is a chemical used to synthesize piperonyl butoxide (PBO), a synergistic agent in the production of bioinsecticides [5]. In this scenario, $P$. hispidinervum has been attracting attention as an alternative and natural source of safrole [6].

It is important to emphasize that the insecticidal activity of $P$. hispidinervum has already been reported in Sitophilus zeamais [7], Tenebrio molitor [8], Spodoptera frugiperda [9], Aedes aegypti, Tetranychus urticae, and Cerataphis lataniae [10], as well as reports of antifungal activities [11], amoebicide [12], nematicide [13], and antimicrobial [14].

Despite the great potential for economic/industrial exploitation, $P$. hispidinervum is still in the process of domestication [15]. It should also be noted that long pepper is an allogamous species [16], with high genetic variability [17]. According to the latter authors, this species has great potential for obtaining varieties with high commercial value; however, it has a deficit of detailed studies regarding germplasm selection and propagation. In this context, Silva et al. [18] warn of the urgent need for research to establish a large-scale production system that enables its commercial planting, germplasm conservation studies and genetic manipulations.

Micropropagation arises, within this context, with a method that allows the clonal propagation of genotypes with characteristics of interest, such as high levels of safrole, and in a relatively short period. However, there are few reports of in vitro cultivation of $P$. hispidinervum aiming at propagation, being restricted, as far as our knowledge goes, to Silva et al. [18], who propagated long pepper plants by proliferation of lateral buds.

Among micropropagation techniques, somatic embryogenesis stands out as a crucial tool for biotechnological purposes, enabling in addition to clonal propagation, cryopreservation of germplasm and genetic transformation, including gene editing. It is worth emphasizing that $P$. hipidinervum is included in the list of priority species for conservation [19], which justifies the development of protocols that allow its conservation [20].

Despite all the benefits of somatic embryogenesis, plants regenerated from somatic embryos can exhibit somaclonal variation $[21,22]$. Therefore, it is necessary to evaluate the stability of the genome of plants regenerated in vitro, especially when the goal is conservation of genetic resources and propagation of genotypes with specific characteristics obtained through breeding programs, which consume money and time [22]. Among the methods used to evaluate genome changes in plants cultivated in vitro, flow cytometry, considered a practical, reliable and fast technique for DNA ploidy screening, is cited [21], as well as reproducible and sensitive [23].

Within this context, the objective was to develop an efficient somatic embryogenesis protocol for Piper hispidinervum from foliar explants, in addition to evaluating the embryogenic potential of different accesses and genetic stability of regenerated plants.

\section{Methods}

\section{Plant material}

The plant material used consisted of foliar explants obtained from plants germinated in vitro of different Piper hispidinervum accesses (PH17, PH21, PH28, PH37, and PH39) selected for oil yield and safrole contents, from the Embrapa Acre Germplasm Bank, Rio Branco, Acre, Brazil.

Initially, the seeds of the different accesses were subjected to disinfestation, characterized by immersion for three minutes in $70 \%$ ethanol $(\mathrm{v} / \mathrm{v})$, followed by immersion for $20 \mathrm{~min}$ in sodium hypochlorite $(\mathrm{NaOCl})(2.0$ $2.5 \%$ active chlorine) and four washings in distilled and autoclaved water. Then, the seeds were inoculated in vials containing $30 \mathrm{ml}$ of MS culture medium [24] plus 30 $\mathrm{g} / \mathrm{l}$ sucrose (Sigma, St. Louis, MO, USA). The $\mathrm{pH}$ of the medium was adjusted to $5.8 \pm 0.1$ prior to the addition of the gelling agent (2.5 g/l Phytagel-Sigma, St. Louis, MO, USA). Sterilization of the medium was carried out by autoclaving at $121{ }^{\circ} \mathrm{C}$ for $20 \mathrm{~min}$ at $1.5 \mathrm{~atm}$ pressure.

The plant material was kept in a growth room under temperature of $25 \pm 2{ }^{\circ} \mathrm{C}$, photoperiod of $16 \mathrm{~h}$ and luminous intensity of $100 \mu \mathrm{mol} . \mathrm{m}^{-2} \cdot \mathrm{s}^{-1}$ supplied by LED lamps (Philips brand, model 920008431). The seeds remained in these conditions until complete germination and reached a height of approximately $6 \mathrm{~cm}$, to then be used as sources of explants for the induction of somatic embryogenesis.

\section{Somatic embryogenesis \\ Somatic embryogenesis establishment}

Leaf segments from plants germinated in vitro were used as explants for the induction of callogenesis of $P$. hispidinervum. For experiment 1 , explants with about $0.5 \mathrm{~cm}^{2}$, coming from different accesses were cultivated in Petri dishes $(15 \times 90 \mathrm{~mm})$ containing MS medium [25] supplemented with $\alpha$-naphthalenoacetic acid (NAA) (Sigma, St. Louis, MO, USA) and 6-benzylaminopurine (BAP) (Sigma, St. Louis, MO, USA) in different combinations, plus $30 \mathrm{~g} / \mathrm{l}$ sucrose and $2.5 \mathrm{~g} / \mathrm{l}$ Phytagel (Sigma, St. Louis, $\mathrm{MO}$, USA). For experiment 2 , explants with about $1 \mathrm{~cm}^{2}$, 
coming from five different Piper hispidinervum accesses (PH17, PH21, PH28, PH37, and PH39) were cultivated in Petri dishes $(15 \times 90 \mathrm{~mm})$ containing MS medium plus $5 \mathrm{mg} / \mathrm{l} \mathrm{NAA}+2.5 \mathrm{mg} / \mathrm{l} \mathrm{BAP}, 30 \mathrm{~g} / \mathrm{l}$ sucrose and $2.5 \mathrm{~g} / \mathrm{l}$ Phytagel. The $\mathrm{pH}$ of the media was adjusted to $5.8 \pm 0.1$ prior to the addition of the gelling agent and the media were sterilized as mentioned in the previous topic.

The leaf segments were inoculated in a laminar flow chamber with the abaxial face in contact with the culture medium and cultivated in the dark in an incubator chamber, type Biochemical Oxygen Demand (B.O.D.) (Percival brand, model I-30NL), with temperature at $25{ }^{\circ} \mathrm{C} \pm 2$ ${ }^{\circ} \mathrm{C}$, for 60 days (experiment 1 ) and 80 days (experiment 2). After 30 and 60 days of cultivation, the percentage of primary calluses (initial calluses without embryogenic potential) formed for experiment 1 and, after 40 days, for experiment 2 , was evaluated. After 80 days of cultivation, the percentage of embryogenic calluses from experiment 2 was evaluated.

The calluses obtained were transferred to MS medium supplemented with $10 \mathrm{mg} / \mathrm{l} \mathrm{NAA}+2.5 \mathrm{mg} / \mathrm{BAP}$. All media were added $30 \mathrm{~g} / \mathrm{l}$ sucrose and $2.5 \mathrm{~g} / \mathrm{l}$ Phytagel. The calluses were kept in the aforementioned environmental conditions and, after 45 days, the percentage of somatic embryos-like structures was evaluated.

\section{Germination of somatic embryos-like structures and acclimatization of plants}

The obtained somatic embryos-like structures were inoculated in Petri dishes with MS medium, plus $30 \mathrm{~g} / \mathrm{l}$ sucrose. The somatic embryos-like structures were kept in growth room with temperature of $25{ }^{\circ} \mathrm{C} \pm 2{ }^{\circ} \mathrm{C}$ and photoperiod of $16 \mathrm{~h}$, for at least 45 days, until the emission of the meristems.

After the germination of somatic embryos-like structures and plant growths, the acclimatization process was carried out [24]. After washing in running water to eliminate the culture medium, the plants were inoculated in plastic cups of $500 \mathrm{~mL}$ containing commercial substrate Bioplant ${ }^{\circledR}$, which were accommodated in trays, covered with plastic bags and taken for incubation for 10 days in incubator chamber (Percival, model I-30NL), with temperature of $25{ }^{\circ} \mathrm{C}$ and photoperiod of $16 \mathrm{~h}$. After acclimatization, the surviving plants were transferred to greenhouse to complete growth.

\section{Experimental design and statistical analysis}

An entirely randomized experimental design was adopted for both experiments. The first experiment consisted of five treatments (combinations of NAA and BAP), with five repetitions with five explants each. The second experiment consisted of five treatments (PH17, PH21, PH28, PH37, and PH39 accesses), with six repetitions with five explants each. The data were submitted to the analysis of variance and the means compared by the Scott-Knott Test at the level of $5 \%$ significance, using the Sisvar 4.0 program [26].

\section{Morphological and anatomical characterization of calluses and somatic embryos-like structures}

For anatomical characterization, samples of foliar explants with primary calluses, embryogenic calluses and somatic embryos-like structures of $P$. hispidinervum were taken. Embryos were fixed in Karnovsky [27] (paraformaldehyde $2 \%$, glutaraldehyde $2.5 \%$, and cacodylate buffer $0.2 \mathrm{~m} \mathrm{pH} \mathrm{7.2)} \mathrm{for} 24 \mathrm{~h}$ in the dissector, under vacuum. The material was dehydrated in increasing ethyl series (30-100\%) and included in methacrylate (Historesin, Leica), prepared according to the manufacturer's instruction.

The blocks were cut longitudinally into sections of 5 $\mu \mathrm{m}$ thick in a rotary microtome (Leica ${ }^{\circledR}, \mathrm{RM} 212 \mathrm{RT}$, Buffalo Grove, IL). The obtained sections were stained with toluidine blue in acid $\mathrm{pH}$ [28]. The observations and photographic documentation were made on an Olympus microscope (AX70), equipped with Leica camera and software for image capture. Three replicates were used for each type of sample.

\section{Analysis of regenerated plants by flow cytometry}

For this analysis, approximately $30-50 \mathrm{mg}$ of leaves were used from young $P$. hispidinervum plants regenerated by somatic embryogenesis, from $P$. hispidinervum plants cultivated in greenhouse from seed germination (mother plants) and from the external reference standard-pea (Pisum sativum L.).

To obtain the nuclei suspension, the plant material was initially crushed in $1.0 \mathrm{ml}$ of Marie extraction buffer [29], already added to the Petri dish in the presence of ice. Then, the crushed tissue in suspension was vacuumed with the aid of Pasteur's pipette and filtered in 41 $\mu \mathrm{m}$ mesh (Millipore). Finally, the nuclei suspension was stained with $25 \mu \mathrm{L}$ of a solution of $1 \mathrm{mg} / 1 \mathrm{~mL}$ of propidium iodide.

In each sample, at least 20,000 nuclei were analyzed regarding fluorescence emission, for relative quantification of nuclear DNA. Histograms were obtained on the Accuri C6 cytometer (Becton Dickinson) and analyzed in the Accuri CFlow Plus BD software. The mean nuclear DNA content, in pictograms (pg), was measured by the equation: DNA amount $(\mathrm{pg})=$ (position of the G1 peak of the sample/position of the G1 peak of the reference standard) $x$ reference DNA [30]. Flow cytometry analysis was performed on 30 randomly selected plants, each repeat being repeated three times. 


\section{Results and discussion}

\section{Somatic embryogenesis establishment}

After 30 days of cultivation, regardless of the treatment tested, the formation of primary calluses with white color and friable consistency was observed, appearing mainly on the leaf ribs and in the regions of section of the explants (Fig. 1). According to statistical analysis, the treatments $2.5 \mathrm{mg} / \mathrm{l} \mathrm{BAP}$ and $5 \mathrm{mg} / \mathrm{l} \mathrm{NAA}+2.5 \mathrm{mg} / \mathrm{l}$ BAP provided each, after 60 days of cultivation, $32 \%$ of primary callus formation (Table 1). Significantly higher percentage of primary calluses, mean value of $87 \%$, was obtained by [24] in leaf segments of $P$. aduncum also cultivated in medium with $5 \mathrm{mg} / \mathrm{l} \mathrm{NAA}+2.5 \mathrm{mg} / \mathrm{l} \mathrm{BAP}$.

As observed in Table 1, callus formation was not observed from explants cultivated in medium devoid of BAP. This regulator, commonly associated with cell division [31], is, according to the citations of the last 5 years [32], the most widely used in vitro cytokinin, with $31 \%$ of citations, possibly due to your effectiveness and accessibility. Singh et al. [33], for example, obtained up to $98.1 \%$ of calluses in leaf segments of Sapindus mukorossi in medium supplemented with $8.88 \mu \mathrm{M}$ BAP. The efficiency

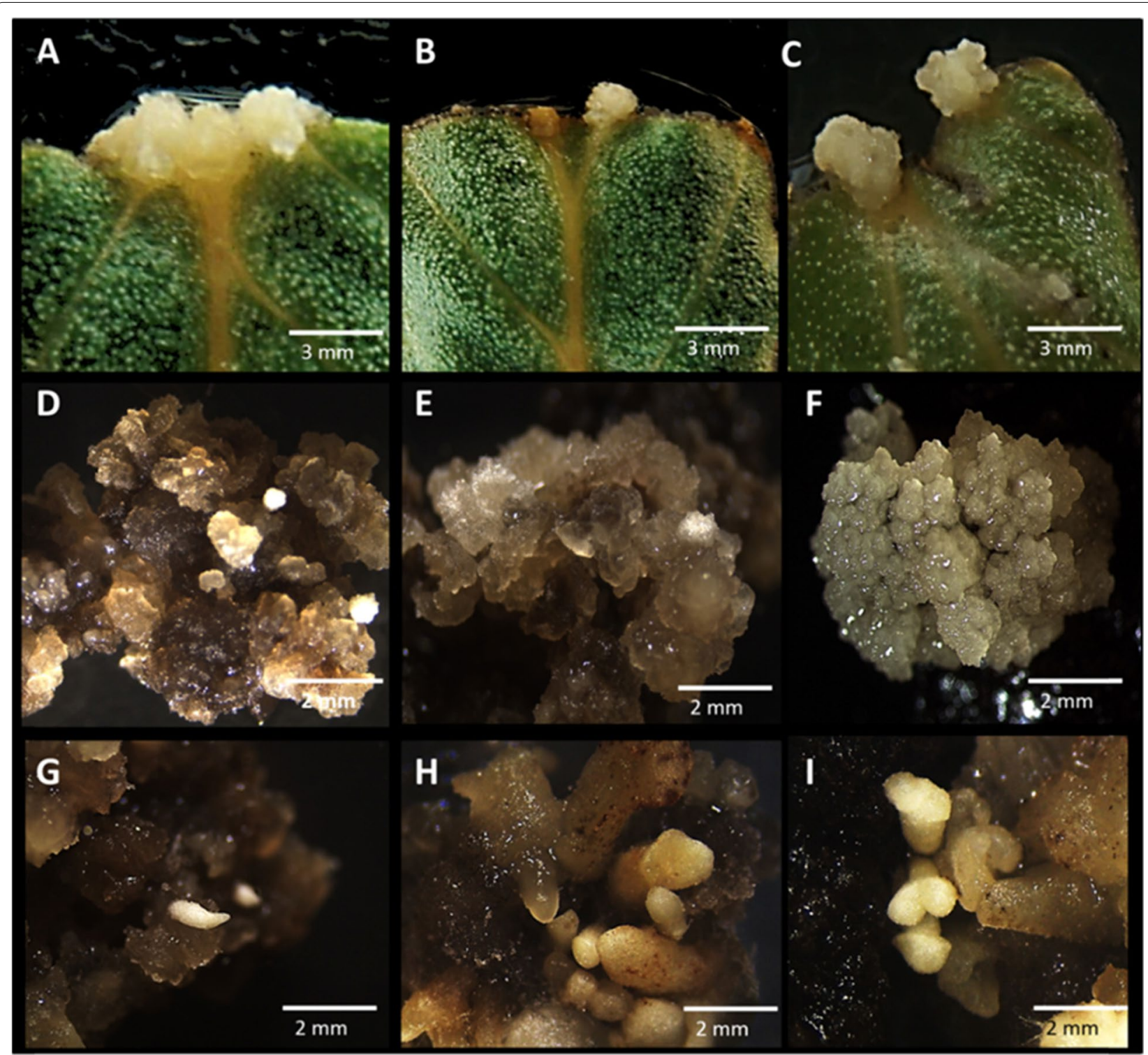

Fig. 1 Formation of primary calluses, embryogenic calluses, and somatic embryos-like structures in different accesses of Piper hispidinervum. A-C Emergence of primary calluses, after 40 days of cultivation. D-F Embryogenic calluses obtained after 80 days cultivation. G-I Differentiated somatic embryos-like structures after 125 days of cultivation 
Table 1 Callus formation from leaf segments of Piper hispidinervum under the effect of different combinations of growth regulators, a-naphtalenoacetic acid (NAA), and 6-benzylaminopurine (BAP), aiming at somatic embryogenesis, after 30 and 60 days of cultivation

\begin{tabular}{lll}
\hline & \multicolumn{2}{l}{ Cultivation time } \\
\cline { 2 - 3 } $\mathbf{N A A}+\mathbf{B A P}\left(\mathbf{m g ~ L}^{-\mathbf{1}}\right)$ & $\mathbf{3 0}$ days & $\mathbf{6 0}$ days \\
\hline $0.0+0.0$ & $0.0 \mathrm{CA}$ & $0.0 \mathrm{cA}$ \\
$5.0+0.0$ & $0.0 \mathrm{cA}$ & $0.0 \mathrm{cA}$ \\
$10.0+0.0$ & $0.0 \mathrm{cA}$ & $0.0 \mathrm{cA}$ \\
$0.0+2.5$ & $4.0 \mathrm{bA}$ & $32.0 \mathrm{aB}$ \\
$5.0+2.5$ & $12.0 \mathrm{aA}$ & $32.0 \mathrm{aB}$ \\
$10.0+2.5$ & $12.0 \mathrm{aA}$ & $12.0 \mathrm{bA}$ \\
Average & $5.0 \mathrm{~A}$ & $20.6 \mathrm{~B}$ \\
\hline
\end{tabular}

*Means followed by the same letter (uppercase for horizontal comparison and lowercase for vertical comparison) do not differ statistically by the Scott-Knott test at $5 \%$ significance

of BAP in the formation of calluses was also mentioned by Patel et al. [34], in Curculigo orchioides, Ren et al. [35] in Griffinia liboniana, and Yusuf et al. [36] in Piper colubrinum.

Differently of the observed for us, Costa et al. [37] verified the formation of calluses from leaf segments of $P$. hipidinervum in medium supplemented only with NAA, with high percentages observed in the concentrations of 2.5 and $5 \mathrm{mg} / \mathrm{l}$. Valle [38] obtained a higher percentage of friable calluses, also in foliar tissues of this species, in medium supplemented with 2,4-D and BAP. These differences in the requirement for different growth regulators, combined or not, may be related to genotypic variations.

There are several reports of the combination NAA and BAP in the induction of calluses, with results varying according to concentration, species and explant, among other factors. For example, the combination of this auxin and cytokinin provided a high percentage of calluses in foliar explants of Panax vietnamensis [39], but it was not efficient for the induction of calluses in Dioscorea spp. [40]. This variability in responses should probably be related to the interaction with endogenous hormones in tissues and a possible specificity of the regulator/ hormone with receptors and/or co-receptors/effectors, which may vary depending on tissue, subcellular compartment and environmental conditions [41].

Once the best treatment for callus induction from foliar explants of Piper hispidinervum was defined, the responsiveness of different genotypes to somatic embryogenesis was evaluated. After 40 days of cultivation in medium with $5 \mathrm{mg} / \mathrm{l} \mathrm{NAA}+2.5 \mathrm{mg} / \mathrm{l} \mathrm{BAP}$, the results of the evaluations showed significant differences with regard to the formation of primary calluses (Figs. $1 \mathrm{~A}-\mathrm{C}$ and 2A). Accesses PH28, PH37, and PH39 presented the highest percentages, with 100,96 , and $90 \%$ of formation, respectively (Fig. 2A).

Subsequently, the primary calluses were transferred to the somatic embryo formation medium, supplemented with a higher concentration of NAA (10 mg/l), which provided gradual oxidation of the primary calluses concomitantly with the formation of embryogenic masses. The embryogenic calluses had no defined shape and exhibited a texture ranging from friable to watery and beige and/or brown coloration (Fig. 1D-F). Morphologically, the friable calluses obtained here resemble those obtained by [37], also derived from leaf segments of $P$. hispidinervum.

In general, auxins are the growth regulators commonly used in the transition from somatic to embryogenic cells, and may or may not be combined with low concentrations of cytokinins [42]. Among the most used auxins in the induction of somatic embryogenesis, 2,4-D and NAA stand out [43]. In some embryogenic systems, such as in Medicago truncatula, the auxin alone (NAA) is not sufficient for the induction of embryogenesis, however, in conjunction with cytokinin (BAP), the process happens [44]. Similarly, the interaction between these two regulators was fundamental for the formation of somatic embryos of Portulaca oleracea [45] and Cucumis melo [46].

As for the percentage of embryogenic calluses (Fig. 2B) and the percentage of somatic embryos-like structures (Fig. 2C), the five accesses tested did not differ, with mean value of $90.6 \%$ and $77.3 \%$, respectively. These results indicate that the combination of NAA and BAP is effective in the induction of somatic embryos-like structures of $P$. hispidinervum, regardless of the access tested, and that foliar explants are efficient for the development of a somatic embryogenesis protocol of the species. In this work, asynchronicity (Fig. 1G-I) was observed in the formation of somatic embryos-like structures, not different from that reported for other species [34, 47, 48], including of the same genera $[37,49]$.

Despite the existence in the literature of several reports regarding the variability in the embryogenic response of different genotypes of the same species using the same induction conditions [46, 50-53], the same was not observed in this work. Differences were found among the genotypes tested only related to the formation of primary (non-embryogenic) calluses, with the lowest rate obtained still considered relatively high (genotype PH 17: 70\%) (Fig. 2A).

According to [43], the beginning of the somatic embryogenesis process is a highly hereditary feature, which opens the possibility that a greater number of efficient genotypes for the induction of this morphogenetic route 


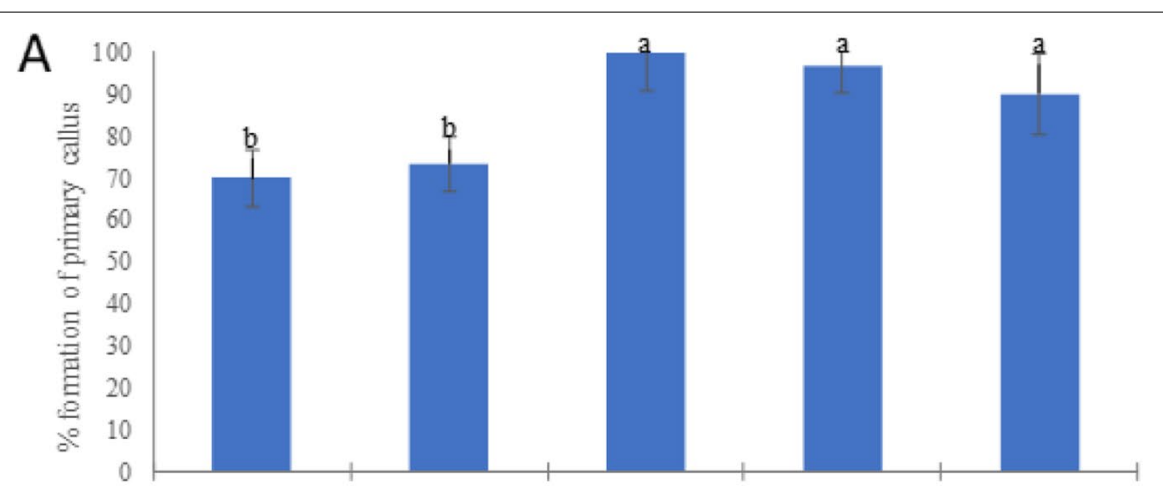

B
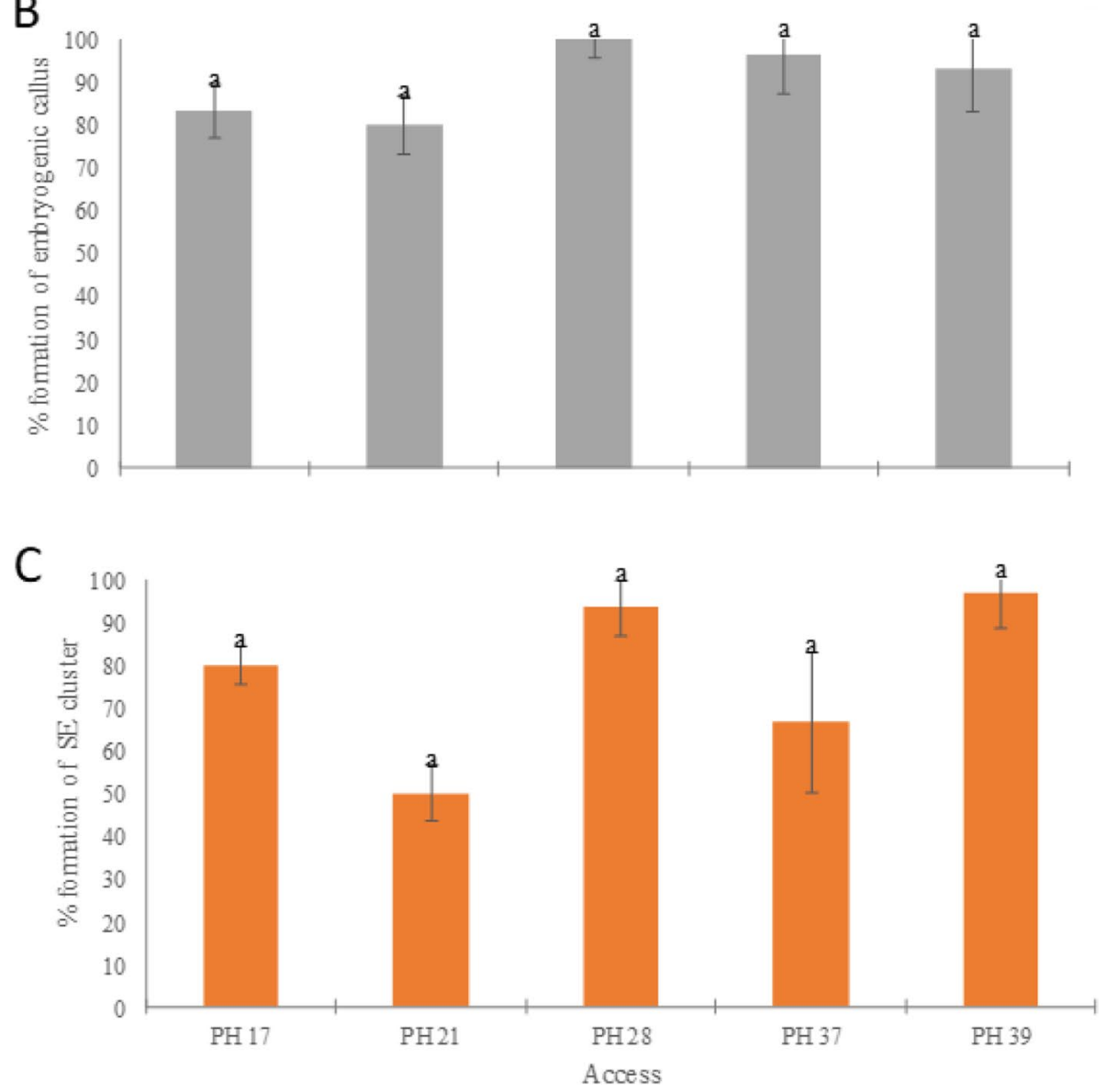

Fig. 2 Somatic embryogenesis from different accesses (PH17, PH21, PH28, PH37, and PH39) of Piper hispidinervum. A Formation of primary calluses. B Formation of embryogenic calluses. C Formation of somatic embryos-like structures (SE) in embryogenic calluses. The bars represent the standard errors. Means followed by the same letter do not differ statistically from each other by the Scott-Knott test at $5 \%$ significance

can be made available through conventional breeding. According to [54], if at least one of the parents with high efficiency in the induction of somatic embryogenesis is included in each breeding pair, there is the possibility of obtaining families with reasonably high initiation rates of somatic embryogenesis. In this context, the relevance of investigating the embryogenic capacity of different higher genotypes of Piper hispidinervum is noted.

It is noteworthy, the apparently positive role of oxidation of primary calluses in the induction of somatic embryogenesis of $P$. hispidinervum, previously reported also in $P$. aduncum [24]. The formation of somatic embryos from oxidized calluses is not a feature limited 


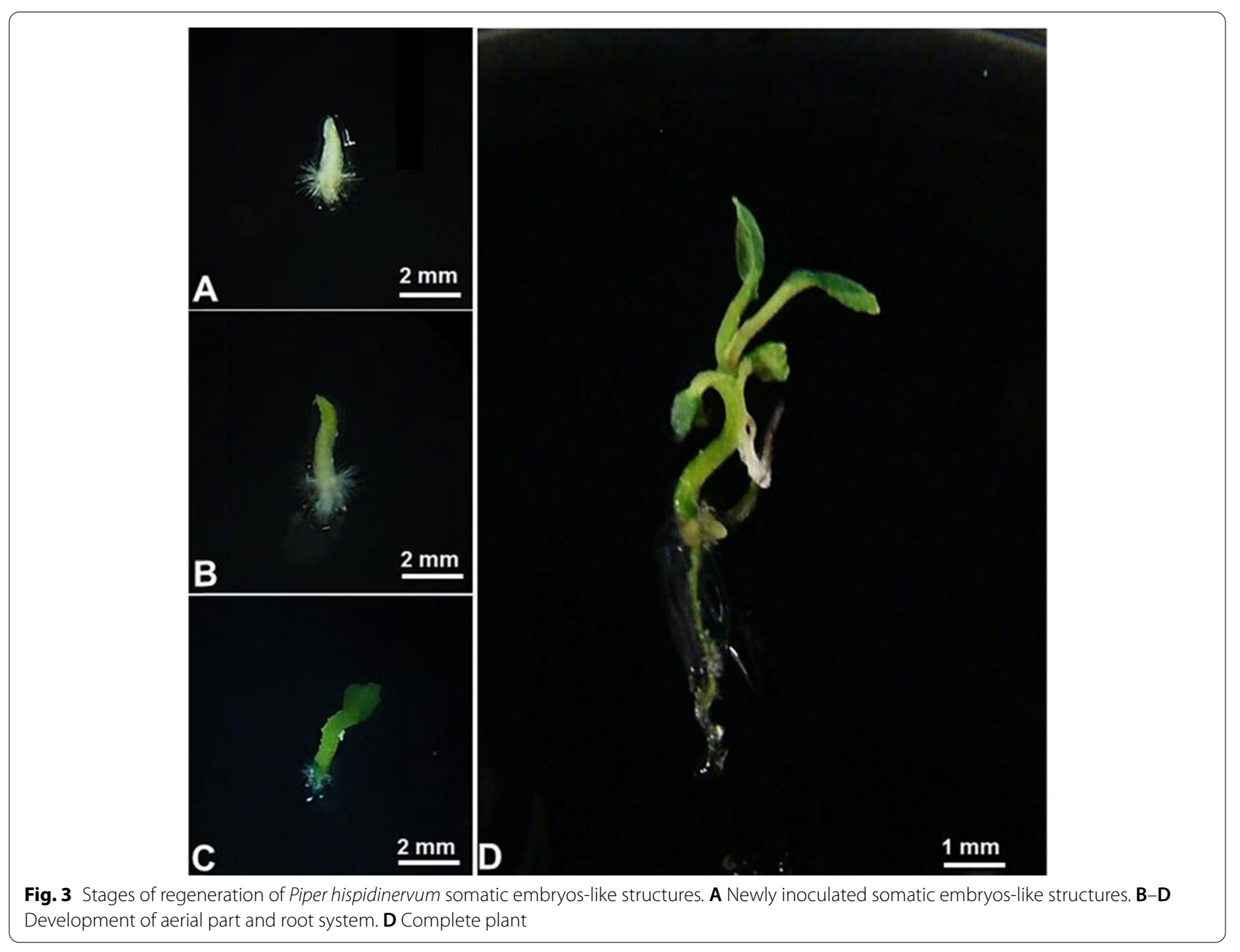

to species of the genus Piper. In Coffea canephora [55], Hevea brasiliensis [56, 57], Arbutus unedo [58], Fraxinus mandshurica [59-61], and Eucalyptus grandis $x$ E. urophylla [62], the darkening of explants has been positively related to somatic embryogenesis and, in some cases, considered a prerequisite for the occurrence of this morphogenetic pathway. According to [60], occurrence of darkening of explants of Fraxinus mandshurica was not only a consequence of the oxidation of phenolic compounds, but mainly of stress-related processes, which in turn are involved with programmed cell death (PCD) and with the induction of somatic embryogenesis.

Some authors consider somatic embryogenesis as an adaptation response of the plant genome to the stresses inherent to in vitro cultivation [63, 64]. According to [65], when the degree of stress exceeds cellular tolerance, the cells collapse and die, on the other hand, when the level of stress is lower, there is an increase in metabolic activity and induction of the adaptation process, including gene expression reprogramming and cell reorganization. It is emphasized that the establishment of somatic embryogenesis is characterized by the expression of numerous genes related to different stresses, especially those encoding transcription factors involved in hormonal signaling and cell differentiation [66]. Some authors have investigated the positive involvement of reactive oxygen species (ROS) in somatic embryogenesis $[57,67]$, which are generally produced under stress conditions [68] and associated with irreversible cellular damage [69]). The non-occurrence of oxidized calluses by overaccumulation of glutathione, an anti-ROS enzyme, reduced the efficiency of somatic embryogenesis in Hevea brasiliensis [57].

According to [70] and, later, Corredoira et al. [71] associated the presence of darkened exudates in embryogenic cultures of $E$. nitens with a possible role of protection against unfavorable environmental conditions during cultivation. More recently, Silva-Cardoso et al. [72] also raised a similar hypothesis when describing the somatic embryogenesis of Syagrus oleracea. In this context, the 

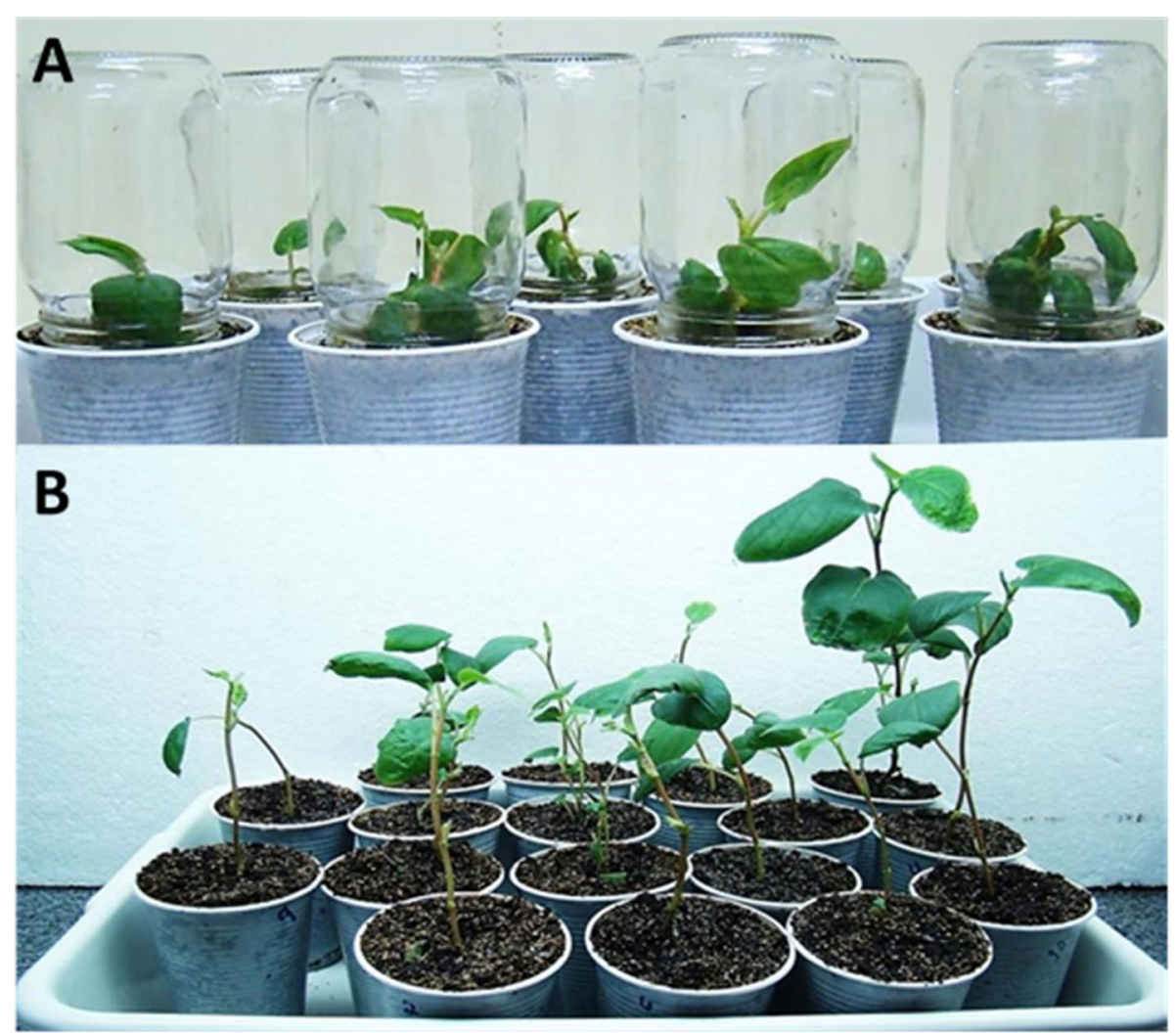

Fig. 4 Plants regenerated by somatic embryogenesis of Piper hispidinervum. A Plants in B.O.D. for acclimatization. B Plants in greenhouse post-acclimatization

effects of oxidation on the acquisition of competence for the somatic embryogenesis route in P. hispidinervum deserves further investigation to elucidate its role.

\section{Germination of somatic embryos-like structures and acclimatization of plants}

The conversion of somatic embryos into plantlets is an important step in somatic embryogenesis process. After 15 days of inoculation in culture medium with MS salts and vitamins devoid of regulators, the somatic embryos-like structures $P$. hispidinervum began to develop (Fig. 3A). Initially, there was the emergence of an axial root presenting area of piliferous layer and root cap (Fig. 3B), followed by the development of the aerial part (Fig. 3C).

After 45 days in germination medium, the P. hispidinervum plants already presented development of root system, stem and lateral buds ideal for acclimatization phase (Fig. 3D), aiming at adaptation to in vitro post-cultivation humidity and temperature conditions (Fig. 4A). The plants transferred to greenhouse, previously acclimatized in incubator chamber, showed $100 \%$ survival
(Fig. 4B). These results indicate high efficiency of the somatic embryogenesis process of $P$. hispidinervum induced by NAA and BAP, similar to the one mentioned for P. aduncum [24].

\section{Morphoanatomical characterization}

Somatic embryogenesis induction protocols from different explants can be developed or optimized through the use of knowledge of anatomical and histochemical aspects related to the origin of somatic embryos, as well as the sequence of events that lead to their development [43]. In addition, anatomical analysis allow the differentiation between somatic embryogenesis and organogenesis routes, which may, depending on the species and general cultivation conditions, occur in the same system. Given its importance, histological analysis of primary calluses, embryogenic calluses, and somatic embryos-like structures of $P$. hispidinervum were performed.

At 40 days of cultivation, primary calluses were visualized, mainly on the ribs of the adaxial region of the explant (Fig. 5A). The formation of calluses in the adjacencies of vascular tissues has been commonly 
mentioned in the literature [73-77] and may be related to phloem proximity, which is responsible for the transport of hormones [78] involved with cell division, and composed of responsive vascular stem cells [76, 79].

The primary calluses presented cells with parenchymatous characteristics, with visible nuclei, large vacuoles, thin cytoplasm and visible cell spaces (Fig. 5A-D). Such characteristics resemble those mentioned for primary calluses of $P$. aduncum [24]. Some smaller cells, evident nuclei, and dense cytoplasm (Fig. 5D) were also found at the edge of the primary calluses, probably cells competent for the subsequent formation of embryogenic calluses. Recently, it were reported morphoanatomic characteristics of two types of primary calluses, one with competence for somatic embryogenesis and the other without [77]. The first was characterized by parenchymatous cells with reduced intercellular spaces, while the second type also presented parenchymatous cells, however, with large intercellular spaces.

In the anatomical sections of the embryogenic calluses Fig. 5E, regions with cells with meristematic, isodiametric characteristics, with dense cytoplasm, evident nuclei, thinner cell walls and absence of intercellular spaces were observed (Fig. 5F). Several cells presented two nuclei in the same cytoplasm, showing the cytokinesis not yet completed in the cell division process. These characteristics have been reported in other embryogenic systems [72, 80, 81].

We also observed clustering of these cells, forming aggregates separated by apparently thicker cell walls and surrounded by purple-colored mucilage, typical characteristics of friable calluses (Fig. 5F). According to [82], mucilaginous substances fill the spaces between cell aggregates, which facilitates the diffusion of nutrients and metabolites into friable calluses. This type of callus has often been considered embryogenic in different species $[77,83]$ and is a prerequisite for the establishment of cell suspension cultures [84].

At 125 days of cultivation, somatic embryos-like structures were observed at different stages of development, including the cotyledonar (Fig. 5G, H), and without any vascular connection with the explant of origin. Somatic embryos-like structures at this stage exhibited protoderm composed of juxtaposed cells, with evident nuclei and tabular format. Below these, some layers of cells with a larger diameter were observed, which characterize a fundamental meristem. In the center, narrow and elongated cells that make up the procambium were observed. Constituting the basal layer of the embryos, the root apex was noted, formed by cells with reduced size compared to the other cells of the embryo, with evident nuclei, dense cytoplasm and isodiametric format. Distinct cotyledons and the apical promeristem were also observed (Fig. $5 \mathrm{H}$ ). The histological analysis performed did not allow to infer on the unicellular or multicellular origin of the somatic embryos-like structures obtained.

\section{Analysis of the nuclear DNA content of plants regenerated by flow cytometry}

The analysis of young leaves of $P$. hispidinervum resulted in tapered G1 DNA peaks, with good resolution, which indicate reliability of the results presented. Representative histograms of the analysis can be viewed in Fig. 6 .

Regarding specifically the nuclear genome size of $P$. hispidinervum plants from somatic embryogenesis and those from greenhouse from seed germination, the estimated content of $1.83 \pm 0.02 \mathrm{pg}$ and $1.86 \pm 0.05 \mathrm{pg}$, respectively, was observed on average. The results indicated that the genome size did not differ significantly among plants, thus demonstrating the genomic stability of the plants regenerated via somatic embryogenesis (Table 2).

The quantification of DNA for species of Piper had already been performed by Samuel et al. [85]. The authors analyzed five species of Piper from the old world (two varieties of $P$. nigrum: $4 \times, 8 \times ; P$. longum: $4 \times ; P$. betle: $4 \times ;$ P. silvestre: $4 \times ;$ P. argyrophyllum: $4 \times$ ) and four of the new world (P. apiculatum: $2 \times ; P$. cernum: $2 \times ; P$. arboreum: $2 \times ;$ P. ornatum: $4 \times$ ) including among them cultivated and wild species. The quantification was performed by Feulgen densitometry and the nuclei analysis was in G2 (4C). According to the authors, wild species tend to have higher DNA content than cultivated species. More recently, Phurailatpam et al. [86], using the flow cytometry technique, identified differences in ploidy between plants of different sexes of $P$. betle (females: $4 \times$ and males: $3 \times$ ).

Flow cytometry has been used to evaluate the genetic stability of regenerants obtained by different in vitro cultivation techniques, including by somatic embryogenesis. Factors such as genotype, explant source, growth regulators, age of cultivation [87], and stress inherent to in vitro

\section{(See figure on next page.)}

Fig. 5 Morphoanatomical characterization of somatic embryogenesis of Piper hispidinervum from foliar explants. A Foliar explant with primary callus after 40 days in induction medium (MS medium with $2.5 \mathrm{mg} \mathrm{L}^{-1} \mathrm{BAP}+5 \mathrm{mg} \mathrm{L}^{-1} \mathrm{NAA}$ ). B Cross-section of leaf evidencing formation of primary callus. C Primary callus. D Anatomical section of primary callus. E Embryogenic callus. F Histology of embryogenic callus; note clustering of cells (rectangle) and purple mucilage $\left(^{*}\right)$. G Embryogenic callus and somatic embryos-like structures (arrow). H Anatomical cut of somatic embryos-like structures; observe cotyledons, apical meristems, procambium, and protoderm (arrow). Abbreviations: (ab) abaxial, (ad) adaxial, (ec) embryogenic callus, (gm) ground meristem, (pc) primary callus, (pd) protoderm, (p) procambium, (ram) root apical meristem and (sam) shoot apical meristem 

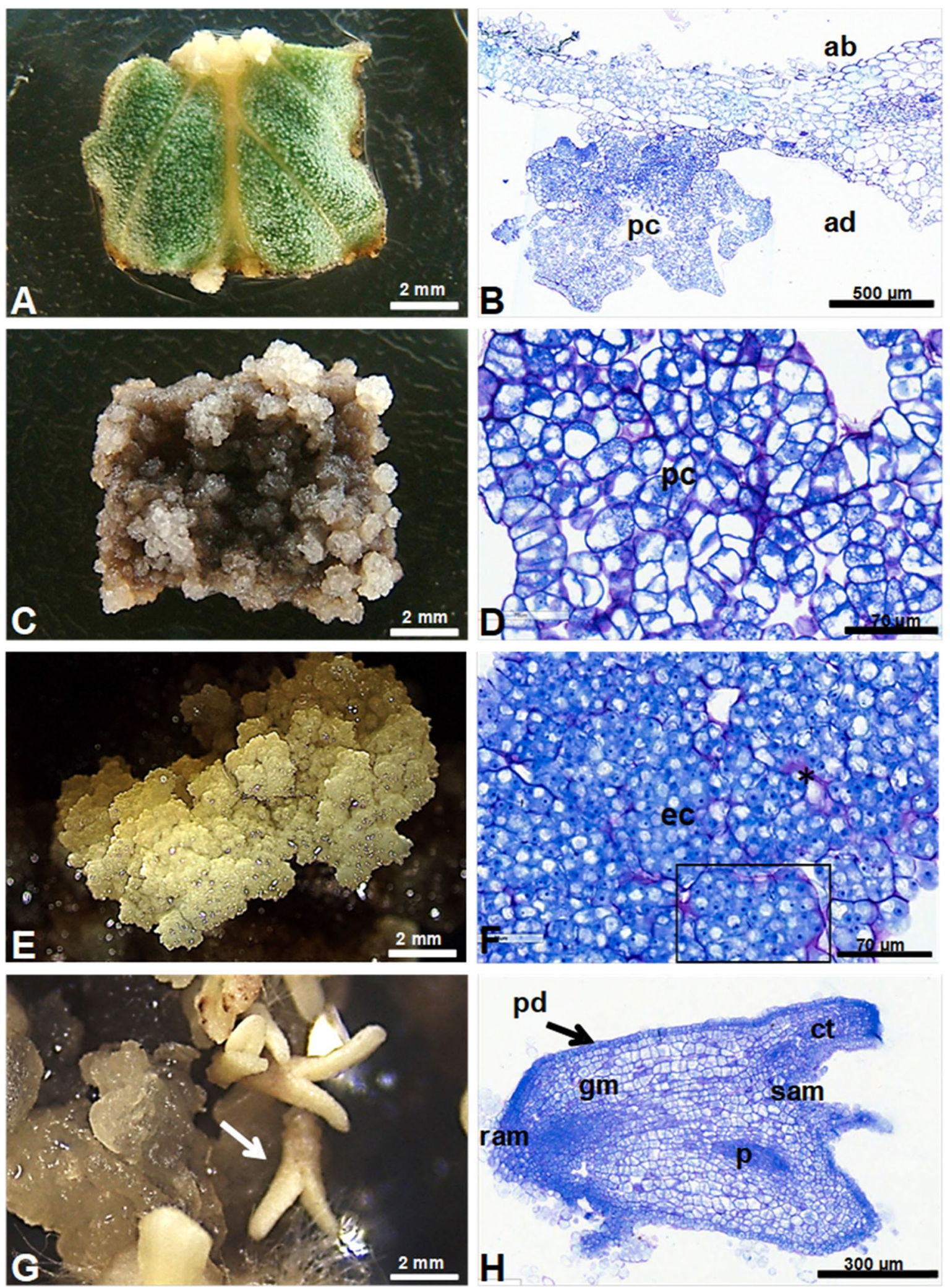

Fig. 5 (See legend on previous page.) 
A

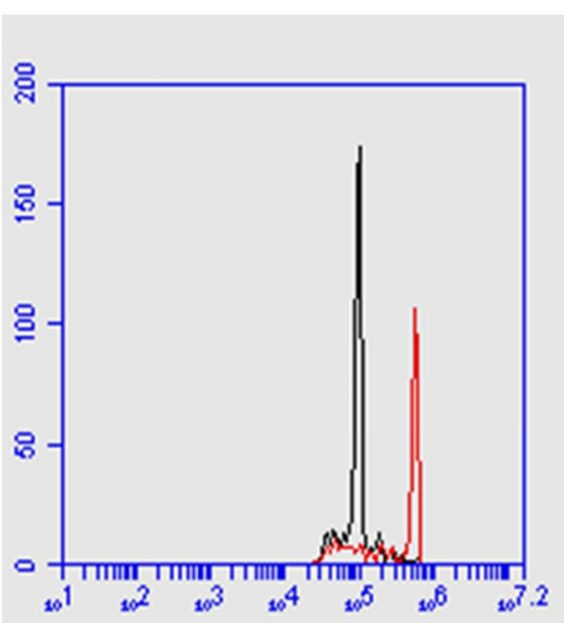

B

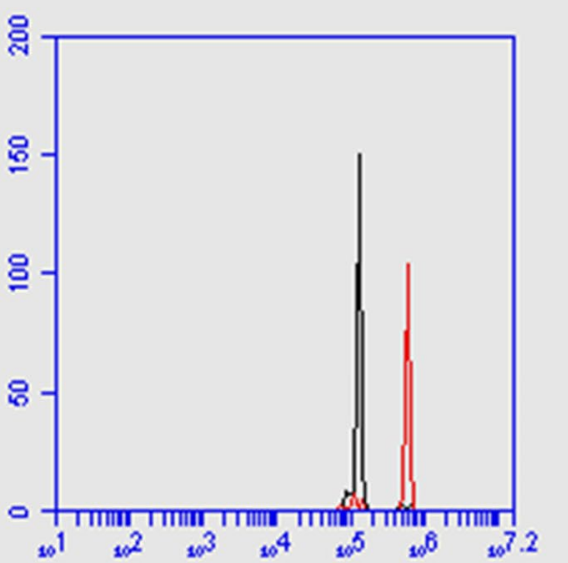

Fig. 6 Histograms relating to flow cytometry analysis of the DNA content in Pepper hispidinervum. The first peak corresponds to P. hispidinervum and the second peak corresponds to the pea reference standard (Pisum sativum L.). A Plants regenerated via somatic embryogenesis and $\mathbf{B}$ Plants grown in greenhouse from seed germination

Table 2 Relative DNA content (pg) between in vitro plants derived from somatic embryogenesis and plants grown in greenhouse from Piper hispidinervum seeds

\begin{tabular}{lllll}
\hline Plants & Peak average & Nuclear DNA content & Genome 1C (Mpb) & CV(\%) \\
\hline Somatic embryogenesis & $126.19^{\mathrm{x}}$ & $1.8329 \pm 0.02 \mathrm{a}^{\mathrm{y}}$ & $891,88^{\mathrm{z}}$ & $4.7^{\vee}$ \\
Seeds (greenhouse) & 123.32 & $1.8666 \pm 0.05 \mathrm{a}$ & 912,76 & 4.6 \\
\hline
\end{tabular}

${ }^{x}$ Calculated from the mean peak G0/G1 of P. hispidinervum in relation to the external reference standard Pisum sativum L.

${ }^{y}$ Means followed by the same letter, belong to the same group, by the Tukey test at the level of $5 \%$ probability

${ }^{z}$ Mean genome size $1 C$, where 1 pg DNA $=978 \mathrm{Mpb}$ (Dolezel et al. 2003)

${ }^{\vee}$ Mean of the coefficient of variation of peak G0/G1

cultivation during somatic embryogenesis itself [21] may affect the genetic stability of regenerated plants. However, in this study, there was no variation in the nuclear DNA content of nuclear plants. P. hispidinervum from the germination of somatic embryos-like structures.

Stability in genome size has also been reported in plants regenerated by somatic embryogenesis of Coriandrum sativum [88], Hibiscus sabdariffa [89], Milkweed spp. [90], Juglans directed [91], and Rauvolfia serpentina [92] evaluated by flow cytometry.

On the other hand, Raji et al. [46] found that $7 \%$ of Cucumis melo plants regenerated via somatic embryogenesis were tetraploid with respect to the mother plant, considered diploid. Despite the identification of this somaclonal variation, the authors consider that the occurrence of similarity with respect to nuclear DNA content in $93 \%$ of regenerated plants is an indication of high genetic stability. There are other reports of significant differences in the DNA content between plants cultivated ex vitro and somatic embryogenesis, as reported by Acanda et al. [93] who obtained coefficient of variation of $5.6 \%$ in the content of vine DNA (Vitis vinifera L. cv. Mencía) obtained from somatic embryogenesis.

In these studies of genomic stability of in vitro cultivations through the flow cytometry technique, the coefficients of variation are essential indications of data reliability and the estimation of the mean DNA content. Marie and Brown [31] proposed coefficients of variation from 1 to $2 \%$ for high-quality results, and around $3 \%$ for routine results. Galbraith et al. [94] defined the value of $5 \%$ for the coefficients of variation, as a criterion for acceptance of DNA content estimates.

The coefficients of variation observed in this work were less than $5 \%$, and in general, ensure the stability and reliability of the somatic embryogenesis method in the production of $P$. hispidinervum clones. 


\section{Conclusions}

In this study, we reported an efficient and unprecedented protocol to regenerate plants via somatic embryogenesis, from foliar explants of superior genotypes of $P$. hispidinervum, in medium supplemented with NAA and BAP. Flow cytometry analysis did not identify variation between plants derived from somatic embryogenesis in relation to plants from seed germination, which supports the use of this protocol for clonal production, germplasm conservation, and genetic transformation of the species.

\section{Acknowledgments}

We wish to thank Dr. Jacson Rondineli S. Negreiros (Embrapa Acre, Rio Branco, Brazil) for providing the biological material for the experiments.

\section{Authors' contributions}

JES-P and PCAS conceived and designed the research. SSSS, IMAS-C and PCAS prepared the plant material, performed the experiments, the anatomic cuts, and acquired the photographs. GNF and JES-P performed the cytometric analysis. PCAS, JES-P and IMAS-C wrote the initial text. JES-P and IMAS-C wrote the final text. All authors read and approved the manuscript.

\section{Funding}

The authors thank the Conselho Nacional de Desenvolvimento Científico e Tecnológico (CNPq Grant 426637/2016-0) and Coordenação de Aperfeiçoamento de Pessoal de Nível Superior (Capes/Embrapa 001-2011/Grant 39) for financial support and fellowships.

\section{Availability of data and materials}

The datasets generated during and/or analyzed during the current study are available from the corresponding author on reasonable request.

\section{Declarations}

Ethics approval and consent to participate

Not applicable.

\section{Consent for publication}

Not applicable.

\section{Competing interests}

The authors declare that they have no competing interests.

\section{Author details}

${ }^{1}$ Universidade de Brasília, Campus Universitário Darcy Ribeiro, Brasília, DF 70910-900, Brazil. Posdoctoral Fellows from the Conselho Nacional de Desenvolvimento Científico e Tecnológico (CNPq, Brasília, Brazil)/Embrapa Recursos Genéticos e Biotecnologia, Brasília, DF, Brazil. Embrapa Recursos Genéticos e Biotecnologia, Av. W5 Norte (final), Brasília, DF 70770-917, Brazil.

Received: 30 September 2021 Accepted: 20 February 2022

Published online: 01 March 2022

\section{References}

1. Salehi B, Zakaria ZA, Gyawali R, Ibrahim SA, Rajkovic J, Shinwari ZK, Khan T, Sharifi-Rad J, Ozleyen A, Turkdonmez E, Valussi M, Tumer TB, Monzote FL, Martorell M, Setzer WN (2019) Piper Species: a comprehensive review on their phytochemistry, biological activities and applications. Molecules 24(7):1364 https://doi.org/10.3390/molecules24071364

2. Nunes JD, Torres GA, Davide LS, Salgado CC (2007) Citogenética de Piper hispidinervum e Piper aduncum. Pesq Agropec Bras 42(7):1049-1052 https://doi.org/10.1590/S0100-204X2007000700019

3. Silva ACPR, Oliveira MN (2000) Caracterização botânica e química de três espécies do gênero Piper no Acre. Embrapa Acre, Rio Branco
4. Bizzo HR, Hovell AMC, Rezende CM (2009) Brazilian essential oils: general view, developments and perspectives. Quim Nova 32:588-594 https:// doi.org/10.1590/S0100-40422009000300005

5. Pimentel FA, Cardoso MG, Salgado APSP, Silva VF, Zarcaroni LM, Morais AR, Nelson DL (2006) Phytochemistry of Piper hispidinervum cultivated under the edafoclimatic conditions of Lavras, MG, Brazil. Nat Prod Ind J 2:89-94

6. Bergo CL, Mendonça HA, Silva MR (2005) Efeito da época e freqüência de corte de pimenta longa (Piper hispidinervum C. DC.) no rendimento de óleo essencial. Acta Amazon 35(2):111-117 https://doi.org/10.1590/ S0044-59672005000200001

7. Estrela JLV, Fazolin M, Catani V, Alécio MR, Lima MS (2006) Toxicidade de óleos essenciais de Piper aduncum e Piper hispidinervum em Sitophilus zeamais. Pesq Agropec Bras 41(2):217-222 https://doi.org/10.1590/ S0100-204X2006000200005

8. Fazolin M, Estrela JLV, Catani V, Alécio MR, de Lima MS (2007) Insecticidal properties of essential oils of Piper hispidinervum C. DC.; Piper aduncum L. and Tanaecium nocturnum (Barb. Rodr.) Bur. \& K. Shum against Tenebrio molitor L. Ciênc Agrotec. 31:113-120 https://doi.org/10.1590/S141370542007000100017

9. Lima RK, Cardoso MG, Moraes JC, Melo BA, Rodrigues VG, Guimarães PL (2009) Insecticidal activity of Long-pepper essential oil (Piper hispidinervum C. DC.) on fall armyworm Spodoptera frugiperda (J. E. Smith, 1797) (Lepidoptera: Noctuidae). Acta Amaz 39:377-382 https://doi.org/10.1590/ S0044-59672009000200016

10. Silva LS, Mar JM, Azevedo SG, Rabelo MS, Bezerra JA, Campelo PH, Machado MB, Trovati G, Santos AL, da Fonseca Filho HD, Souza TP, Sanches EA (2019) Encapsulation of Piper aduncum and Piper hispidinervum essential oils in gelatin nanoparticles: a possible sustainable control tool of Aedes aegypti, Tetranychus urticae and Cerataphis lataniae. J Sci Food Agric 99(2):685-695 https://doi.org/10.1002/jsfa.9233

11. Zacaroni LM, Cardoso MG, Souza PE, Pimentel FA, Guimarães LGL, Salgado APSP (2009) Potencial fungitóxico do óleo essencial de Piper hispidinervum (pimenta longa) sobre os fungos fitopatogênicos Bipolaris sorokiniana, Fusarium oxysporum e Colletotrichum gloeosporioides. Acta Amaz. 39:193-198 https://doi.org/10.1590/S0044-59672009000100020

12. Sauter IP, Rossa GE, Lucas AM, Cibulski SP, Roehe PM, Alves da Silva LA, Rotta MB, Vargas RMF (2012) Chemical composition and amoebicidal activity of Piper hispidinervum (Piperaceae) essential oil. Ind Crop Prod 40:292-295 https://doi.org/10.1016/j.indcrop.2012.03.025

13. Andrés MF, Rossa GE, Cassel E, Vargas RMF, Santana O, Díaz CE, GonzálezColoma A (2017) Biocidal effects of Piper hispidinervum (Piperaceae) essential oil and synergism among its main components. Food Chem Toxicol 109(2):1086-1092 https://doi.org/10.1016/j.fct.2017.04.017

14. Majolo C, Monteiro PC, Nascimento AVP, Chaves FCM, Gama PE, Bizzo HR, Chagas EC (2019) Essential Oils from Five Brazilian Piper Species as Antimicrobials Against Strains of Aeromonas hydrophila. J Essent Oil Bear PI 22(3):746-761 https://doi.org/10.1080/0972060X.2019.1645047

15. Sousa MMM, Lédo FJS, Pimentel FA (2001) Efeito da adubação e do calcário na produção de matéria seca e de óleo essencial de pimenta-longa. Pesq Agropec Bras 36(3):405-409 https://doi.org/10.1590/S0100-204X2 001000300002

16. Wadt LHO, Kageyama PY (2004) Estrutura genética e sistema de acasalamento de Piper hispidinervum. Pesq Agropec Bras 39:151-157 https://doi. org/10.1590/S0100-204X2004000200008

17. Wadt LHO, Ehringhaus C, Kageyama PY (2004) Genetic diversity of "Pimenta Longa" genotypes (Piper spp., Piperaceae) of the Embrapa Acre germplasm collection. Genet Mol Biol 27(1):74-82 https://doi.org/10. 1590/S1415-47572004000100013

18. Silva TL, Balzon TA, Scherwinski-Pereira JE (2012) A rapid in vitro protocol for propagation of Piper aduncum and Piper hispidinervum, two species from Amazon region with multipurpose uses. Afr J Biotechnol 11(89):15539-15546 https://doi.org/10.5897/AJB12.1888

19. Vieira RF, Silva SR (2002) Estratégias para conservação e manejo de recursos genéticos de plantas medicinais e aromáticas: resultados da $1^{\text {a }}$ reunião técnica. Embrapa Recursos Genéticos e Biotecnologia, Brasília

20. Silva TL, Scherwinski-Pereira JE (2011) In vitro conservation of Piper aduncum and Piper hispidinervum under slow-growth conditions. Pesq Agropec Bras 46(4):384-389 https://doi.org/10.1590/S0100-204X201100 0400007

21. Clarindo WR, Carvalho CR, Arauojo FS, Abreu IS, Otoni WC (2008) Recovering polyploid papaya in vitro regenerants as screened by flow cytometry. 
Plant Cell Tissue Organ Cult 92:207-214 https://doi.org/10.1007/ s11240-007-9325-1

22. Bradaï F, Pliego-Alfaro F, Sánchez- Romero C (2016) Somaclonal variation in olive (Olea europaea L.) plants regenerated via somatic embryogenesis: Influence of genotype and culture age on phenotypic stability. Sci Hort 213:208-215 https://doi.org/10.1016/j.scienta.2016.10.031

23. Guo H-H, Wu J-F, Chen C-X, Wang H-M, Zhao Y-L, Zhang C, Jia YH, Liu F, Ning T-Y, Chu Z-H, Zeng F-C (2019) Identification and characterization of cell cultures with various embryogenic/regenerative potential in cotton based on morphological, cytochemical, and cytogenetical assessment. $J$ Integr Agr 18(01):1-8 https://doi.org/10.1016/S2095-3119(17)61876-8

24. Sousa PCA, Souza SSSE, Meira FS, Meira RO, Gomes HT, Silva-Cardoso IMA, Scherwinski-Pereira JE (2020) Somatic embryogenesis and plant regeneration in Piper aduncum L. In Vitro Cell Dev-PI 56:618-633 https:// doi.org/10.1007/s11627-020-10110-y

25. Murashige T, Skoog F (1962) A revised medium for rapid growth and bioassays with tobacco tissue cultures. Phys Plant 15:473-497 https://doi. org/10.1111/j.1399-3054.1962.tb08052.x

26. Ferreira DF (2011) Sisvar: a computer statistical analysis system. Cienc Agrotecnol. 35(6):1039-1042 https://doi.org/10.1590/S1413-7054201100 0600001

27. Karnovsky MJ (1965) A formaldehyde-glutaraldehyde fixative of high osmolality for use in eletron microscopy. J Cell Biol 27:137-138

28. O'Brien TP, Mccylly ME (1981) The study of plant structure: principles and selected methods. Termarcarphi PTY, Melbourne

29. Marie D, Brown S (1993) A cytometric exercise in plant DNA histograms, with 2 C values for 70 species. Bio Cell 78:41-51

30. Dolezel J, Greilhuber J, Suda J (2007) Flow cytometry with plants: an overview. In: Dolezel J, Greilhuber J, Suda J (eds) Flow cytometry with plant cells: analysis of genes, chromosomes and genomes. WILEYVCH Verlag GmbH \& Co, Berlin, pp 41-65

31. Danin M, Upfold SJ, Levin N, Nadel BL, Altman A, van Staden J (1993) Polyamines and cytokinins in celery embryogenic cell cultures. Plant Growth Regul 12:245-254 https://doi.org/10.1007/BF00027205

32. Herman EB (2015) Recent advances in plant tissue culture XXI. Media and techniques for growth, regeneration and storage: 2011-2015. Agritech Consultants Inc., Shrub Oak

33. Singh R, Rai MK, Kumari N (2015) Somatic Embryogenesis and Plant Regeneration in Sapindus mukorossi Gaertn. from Leaf-Derived Callus Induced with 6-Benzylaminopurine. Appl Biochem Biotechnol. 177(2):498-510 https://doi.org/10.1007/s12010-015-1758-0

34. Patel S, Jasrai YT, Adiyecha R (2011) Induction of somatic embryogenesis and genetic fidelity of endangered medicinal herb Curculigo orchioides Gaertn. Res Plant Biol 1(3):48-52

35. Ren Z, Lv X, Zhang D, Xia Y (2018) Efficient somatic embryogenesis and bulblet regeneration of the endangered bulbous flower Griffinia liboniana. Plant Cell Tissue Organ Cult 135(3):523-533 https://doi.org/10.1007/ s11240-018-1484-8

36. Yusuf A, Tyagi RK, Malik SK (2001) Somatic embryogenesis and plantlet regeneration from leaf segments of Piper colubrinum. Plant Cell Tissue Organ Cult 65:255-258 https://doi.org/10.1023/A:1010678609606

37. Costa FHS, Loureiro TS, Scherwinski Pereira JE (2008) Influência de auxinas e tipos de explantes na indução de calos friáveis em Piper hispidinervum C. DC Rev Ciên Agron 39(2):269-274

38. Valle RCSC (2003) Estratégias de cultivo de células de pimenta longa (Piper hispidinervium) e determinação de parâmetros cinéticos. Thesis, Federal University of Santa Catarina, Florianópolis, Santa Catarina. pp 184.

39. Hien VT, Huy NP, Vinh BVT, Chien HX, Tung HT, Nam NB, Luan VQ, Nhut DT (2016) Somatic embryogenesis from leaf transverse thin cell layer derived-callus of vietnamese ginseng (Panax vietnamensis Ha et Grushv.). Vietnam J Biotechnol 14(1):63-73 https://doi.org/10.15625/1811-4989/ $14 / 1 / 9294$

40. Chukwunalu O, Balogun M, Maroya N, Asiedu R (2019) Development of micropropagation system for yam (Dioscorea spp.) using somatic embryogenesis. In: Improving Yam Micropropagation, International Institute of Tropical Agriculture. YIIFSWA Research Brief, Nigeria, pp 1-8

41. Phillips GC, Garda M (2019) Plant tissue culture media and practices: an overview. In Vitro Cell Dev-PI 55:242-257 https://doi.org/10.1007/ s11627-019-09983-5

42. Gaj M (2004) Factors influencing somatic embryogenesis induction and plant regeneration with particular reference to Arabidopsis thaliana (L.)
Heynh. Plant Growth Regul. 43:27-47 https://doi.org/10.1023/B:GROW. 0000038275.29262.fb

43. Corredoira E, Merkle SA, Martínez MT, Toribio M, Canhoto JM, Correia SI, Ballester A, Vieitez AM (2019) Non-Zygotic Embryogenesis in Hardwood Species. Crit Rev Plant Sci 38:1-69 https://doi.org/10.1080/07352689. 2018.1551122

44. Rose RJ (2019) Somatic Embryogenesis in the Medicago truncatula Model: Cellular and Molecular Mechanisms. Front Plant Sci. 10(267):1-14 https:// doi.org/10.3389/fpls.2019.00267

45. Sedaghati B, Haddad R, Bandehpour M (2018) Efficient plant regeneration and Agrobacterium-mediated transformation via somatic embryogenesis in purslane (Portulaca oleracea L.): an important medicinal plant. Plant Cell, Tissue Organ Cult 136(4) https://doi.org/10.1007/s11240-018-1509-3

46. Raji MR, Lotfi M, Tohidfar M, Zahedi B, Carra A, Abbate L, Carimi F (2018) Somatic embryogenesis of muskmelon (Cucumis melo L.) and genetic stability assessment of regenerants using flow cytometry and ISSR markers. Protoplasma 255:873-883 https://doi.org/10.1007/s00709-017-1194-9

47. Raomai S, Kumaria S, Tandon P (2014) Plant regeneration through direct somatic embryogenesis from immature zygotic embryos of the medicinal plant, Paris polyphylla Sm. Plant Cell Tissue Organ Cult 118:445-455 https://doi.org/10.1007/s11240-014-0496-2

48. Batista TR, Mendonça EG, Pádua MS, Stein VC, Paiva L (2018) Morpho and cytological differentiation of calli of Eucalyptus grandis $\times$ Eucalyptus urophylla During somatic embryogenesis. Braz Arch Biol Techn 61:1-11 https://doi.org/10.1590/1678-4324-2018170043

49. Joseph B, Joseph D, Philip VJ (1996) Plant regeneration from somatic embryos in black pepper. Plant Cell Tissue Organ Cult 47:87-90. https:// doi.org/10.1007/BF02318970

50. Kaparakis G, Alderson PG (2008) Role for cytokinins in somatic embryogenesis of pepper (Capsicum annuum L.)? J Plant Growth Regul 27:110-114 https://doi.org/10.1007/s00344-007-9037-0

51. Pinto DLP, Almeida AMR, Rêgo MM, Silva ML, Oliveira EJ, Otoni WC (2011) Somatic embryogenesis from mature zygotic embryos of commercial passionfruit (Passiflora edulis Sims) genotypes. Plant Cell Tissue Organ Cult 107:521-530 https://doi.org/10.1007/s11240-011-0003-y

52. Granja MMC, Motoike SY, Andrade APS, Correa TR, Picoli EAT, Kuki KN (2018) Explant origin and culture media factors drive the somatic embryogenesis response in Acrocomia aculeata (Jacq.) Lodd. ex Mart., an emerging oil crop in the tropics. Ind Crop Prod 177:1-12 https://doi.org/ 10.1016/j.indcrop.2018.02.074

53. Li J, Wang M, Li Y, Zhang Q, Lindsey K, Daniell H, Jin S, Zhang X (2019) Multi-omics analyses reveal epigenomics basis for cotton somatic embryogenesis through successive regeneration acclimation process. Plant Biotechnol J 17(2):435-450 https://doi.org/10.1111/pbi.12988

54. Bonga JM (2016) Conifer clonal propagation in tree improvement programs. In: Park Y-S, Bonga JM, Moon H-K (eds) Vegetative Propagation of Forest Trees. National Institute of Forest Science (NiFos), Korea, pp 3-31

55. Pierson ES, Van Lammeaen AAM, Schel JHN, Staritsky G (1983) In vitro development of embryoids from punched leaf discs of Coffea canephora. Protoplasma 115(2-3):208-216 https://doi.org/10.1007/BF0127981 1

56. Leclerca J, Martin F, Sanier C, Clément-Vidal A, Fabre D, Oliver G, Lardet L, Ayar A, Peyramard M, Montoro P (2012) Over-expression of a cytosolic isoform of the HbCuZnSOD gene in Hevea brasiliensis changes its response to a water deficit. Plant Mol Biol 80(3):255-272 https://doi.org/ 10.1007/s11103-012-9942-x

57. Martin F, Abati V, Burel A, Clément-Vidal A, Sanier C, Fabre D, Woraathasin N, Rio M, Besret P, Farinas B, Montoro P, Leclercq J (2018) Overexpression of EcGSH1 induces glutathione production and alters somatic embryogenesis and plant development in Hevea brasiliensis. Ind Crop Prod 112:803-814 https://doi.org/10.1016/j.indcrop.2017.12.057

58. Martins JF, Santos T, Correia SI, Canhoto JM (2016) Somatic embryogenesis in Arbutus unedo L. and other Ericaceae. In: Park Y-S, Bonga JM, Moon $\mathrm{H}-\mathrm{K}$ (eds) Vegetative Propagation of Forest Trees. National Institute of Forest Science (NiFos), Seoul, pp 491-514

59. Yang L, Bian L, Shen HL, Li YH (2013) Somatic embryogenesis and plantlet regeneration from mature zygotic embryos of Manchurian ash (Fraxinus mandshurica Rupr.). Plant Cell Tissue Organ Cult 115:115-125 https://doi. org/10.1007/s11240-013-0345-8

60. Liu CP, Yang L, Shen HL (2015) Proteomic analysis of immature Fraxinus mandshurica cotyledon tissues during somatic embryogenesis: effects 
of explant browning on somatic embryogenesis. Int J Mol Sci 16:1369213713 https://doi.org/10.3390/ijms160613692

61. Yang L, Wei C, Huang C, Liu H, Zhang D, Shen H, Li Y (2019) Role of hydrogen peroxide in stress-induced programmed cell death during somatic embryogenesis in Fraxinus mandshurica. J For Res 30(3):767-777 https:// doi.org/10.1007/s11676-019-00908-x

62. Moura LC, Xavier A, Cruz ACF, Batista DS, Gallo R, Miranda NA, Otoni WC (2019) Effect of calcium, BAP and putrescine on somatic embryo induction in juvenile explants of Eucalyptus grandis $\times$ E. urophylla hybrids. Aust J Crop Sci 13(04):513-519 https://doi.org/10.21475/ajcs.19.13.04.p1345

63. Dudits D, Györgyey J, Bögre L, Bako L (1995) Molecular biology of somatic embryogenesis In: Thorpe TA (ed) In vitro Embryogenesis in Plants. Kluwer Academic Publishers, Dordrecht, pp 267-308 https://doi.org/10. 1007/978-94-011-0485-2

64. Nowak K, Gaj MD (2016) Stress-related function of bHLH109 in somatic embryo induction in Arabidopsis. J Plant Physiol 193:119-126 https://doi. org/10.1016/j.jplph.2016.02.012

65. Altamura MM, Rovere FD, Fattorini L, D'angeli S, Falasca G (2016) Recent advances on genetic and physiological bases of in vitro somatic embryo formation. In: Germanà MA, Lambardi M (eds) In vitro embryogenesis in higher plants - Methods in molecular biology. Springer, New York, pp 47-85

66. Salaün C, Lepiniec L, Dubreucq B (2021) Genetic and molecular control of somatic embryogenesis. Plants 10:1467 https://doi.org/10.3390/plant s10071467

67. Ma L, Xie L, Lin G, Jiang S, Chen H, Li H, Takac T, Samaj J, Xu C (2012) Histological changes and differences in activities of some antioxidant enzymes and hydrogen peroxide content during somatic embryogenesis of Musa AAA cv. Yueyoukang 1. Sci Hortic 144:87-92 https://doi.org/10.1016/j. scienta.2012.06.039

68. Sharma P, Jha AB, Dubey RS, Pessarakli M (2012) Reactive oxygen species, oxidative damage, and antioxidative defense mechanism in plants under stressful conditions. J Bot 2012:1-26 https://doi.org/10.1155/2012/ 217037

69. Gill SS, Tuteja N (2010) Reactive oxygen species and antioxidante machinery in abiotic stress tolerance in crop plants. Plant Physiol Biochem 48:909-930 https://doi.org/10.1016/j.plaphy.2010.08.016

70. Bandyopadhyay S, Hamill JD (2000) Ultrastructural studies of somatic embryos of Eucalyptus nitens and comparisons with zygotic embryos found in mature seeds. Ann. Bot. 86:237-244 https://doi.org/10.1006/ anbo.2000.1192

71. Corredoira E, Ballester A, Ibarra M, Vieitez AM (2015) Induction of somatic embryogenesis in explants of shoot cultures established from adult Eucalyptus globulus and E. saligna X E. maidenii trees. Tree Physiol. 35:678-690 https://doi.org/10.1093/treephys/tpv028

72. Silva-Cardoso IMA, Meira FS, Gomes ACMM, Scherwinski-Pereira JE (2019) Histology, histochemistry and ultrastructure of pre-embryogenic cells determined for direct somatic embryogenesis in the palm tree Syagrus oleracea. Physiol. Plant. https://doi.org/10.1111/ppl.13026

73. Guzzo F, Baldan B, Mariani P, Lo Schiavo F, Terzi M (1994) Studies on the origin of totipotent cells in explants of Daucus carota L. J Exp Bot 45(279):1427-1432 https://doi.org/10.1093/jxb/45.10.1427

74. Berthouly M, Michaux-Ferrière NM (1996) High frequency somatic embryogenesis in Coffea canephora. Plant Cell Tissue Organ Cult 44:169-176 https://doi.org/10.1007/BF00048196

75. Yusoff NFM, Alwee SSRS, Abdullah MO, Chai-Ling H, Namasivayam P (2012) A time course anatomical analysis of callogenesis from young leaf explants of oil palm (Elaeis guineensis Jacq.). J Oil Palm Res. 24:1330-1341

76. Liu J, Sheng L, Xu Y, Li J, Yang Z, Huang H, Xu L (2014) WOX11 and 12 WOX 11 and 12 are involved in the first-step cell fate transition during de novo root organogenesis in Arabidopsis. Plant Cell 26(3):1081-1093 https://doi.org/10.1105/tpc.114.122887

77. Bartos PMC, Gomes HT, Gomes SM, Vasconcelos Filho SC, Teixeira JB, Scherwinski-Pereira JE (2018) Histology of somatic embryogenesis in Coffea arabica L. Biologia 73(12):1255-1265 https://doi.org/10.2478/ s11756-018-0131-5

78. Petrášek J, Friml J (2009) Auxin transport routes in plant development Development 136:2675-2688 https://doi.org/10.1242/dev.030353

79. Jiang F, Feng Z, Liu H, Zhu J (2015) Involvement of plant stem cells or stem cell-like cells in dedifferentiation. Front Plant Sci 6:1028 https://doi. org/10.3389/fpls.2015.01028
80. Corredoira E, Vieitez AM, Ballester A (2002) Somatic embryogenesis in Elm. Ann Bot 89(5):637-644 https://doi.org/10.1093/aob/mcf080

81. Oliveira EJ, Koehler AD, Rocha DI, Vieira LM, Pinheiro MVM, Matos EM, Cruz ANF, Silva TCR, Tanaka FAO, Nogueira FTS, Otoni WC (2017) Morphohistological, histochemical, and molecular evidences related to cellular reprogramming during somatic embryogenesis of the model grass Brachypodium distachyon. Protoplasma 254:2017-2034 https://doi.org/10. 1007/s00709-017-1089-9

82. Fransz PF, Schel JHN (1991) Cytodifferentiation during the development of friable embryogenic callus of maize (Zea mays). Can J Botany 69:26-33 https://doi.org/10.1139/b91-005

83. Dhanya J, Leen NA, Deepthi DC, Moushmi M, Beena MR, Sheela MN Makeshkumar T (2017) Comparative potential of somatic embryogenesis and friable embryogenic callus production in farmer preferred indian cassava cultivars. J Root Crops 43:23-33

84. Gourguillon L, Rustenholz C, Lobstein A, Gondet L (2018) Callus induction and establishment of cell suspension cultures of the halophyte Armeria maritima (Mill.) Willd. Sci Hortic 233:407-411 https://doi.org/10.1016/j. scienta.2017.08.001

85. Samuel R, Smith JB, Bennett MD (1986) Nuclear DNA variation in Piper (Piperaceae). Can J Genet Cytol 28(6):1041-1043 https://doi.org/10.1139/ g86-145

86. Phurailatpam AK, Geetha KA, Maiti S (2018) Ploidy distinction in male and female plants of betelvine (Piper betle L.): a study by flow cytometry. Genet Resour Crop Evol 65:1565-1570 https://doi.org/10.1007/ s10722-018-0654-1

87. Brar D, Jain SM (1998) Somaclonal variation: Mechanism and applications in crop improvement. In: Jain SM, Brar DS, Ahloowalia BS (eds) Somaclonal variation and induced mutations in crop improvement. Springer, Dordrecht, pp 15-37 https://doi.org/10.1007/978-94-015-9125-6

88. Ali M, Mujib A, Tonk D, Zafar N (2016) Plant regeneration through somatic embryogenesis and genome size analysis of Coriandrum sativum L. Protoplasma 254(1):343-352 https://doi.org/10.1007/s00709-016-0954-2

89. Konar S, Karmakar J, Ray A, Adhikari S, Bandyopadhyay TK (2018) Regeneration of plantlets through somatic embryogenesis from root derived calli of Hibiscus sabdariffa L. (Roselle) and assessment of genetic stability by flow cytometry and ISSR analysis. PLoS One 13(8):e0202324 https:// doi.org/10.1371/journal.pone.0202324

90. Sakhanokho HF, Babiker EM, Smith BJ, Drackett PR (2019) High-frequency somatic embryogenesis, nuclear DNA estimation of milkweed species (Asclepias latifolia, A. speciosa, and A. subverticillata), and genome size stability of regenerants. Plant Cell Tissue Organ Cult 137:149-156 https:// doi.org/10.1007/s11240-019-01559-w

91. Sadat-Hosseini M, Vahdati K, Leslie CA (2019) Germination of Persian Walnut Somatic Embryos and Evaluation of their Genetic Stability by ISSR Fingerprinting and Flow Cytometry. Hortscience 54(9):1576-1580 https:// doi.org/10.21273/HORTSCI13787-18

92. Zafar N, Mujib A, Ali M, Tonk D, Gulzar B, Malik M, Sayeed R, Mamgain J (2019) Genome size analysis of field grown and tissue culture regenerated Rauvolfia serpentina (L) by flow cytometry: Histology and scanning electron microscopic study for in vitro morphogenesis. Ind Crop Prod 128:545-555 https://doi.org/10.1016/j.indcrop.2018.11.049

93. Acanda Y, Prado MJ, González MV, Rey M (2013) Somatic embryogenesis from stamen filaments in grapevine (Vitis vinifera L. Cv. Mencía): changes in ploidy level and nuclear DNA content. In Vitro Cell Dev Biol Plant 49:276-284 https://doi.org/10.1007/s11627-013-9499-7

94. Galbraith DW, Lambert G, Macas J, Dolezel J (2002) Analysis of nuclear DNA content and ploidy in higher plants. In: Robinson J, Azmi A, Tutois S (eds) Current Protocols in Cytometry. Wiley, New York https://doi.org/10. 1002/0471142956.cy0706s02

\section{Publisher's Note}

Springer Nature remains neutral with regard to jurisdictional claims in published maps and institutional affiliations. 